
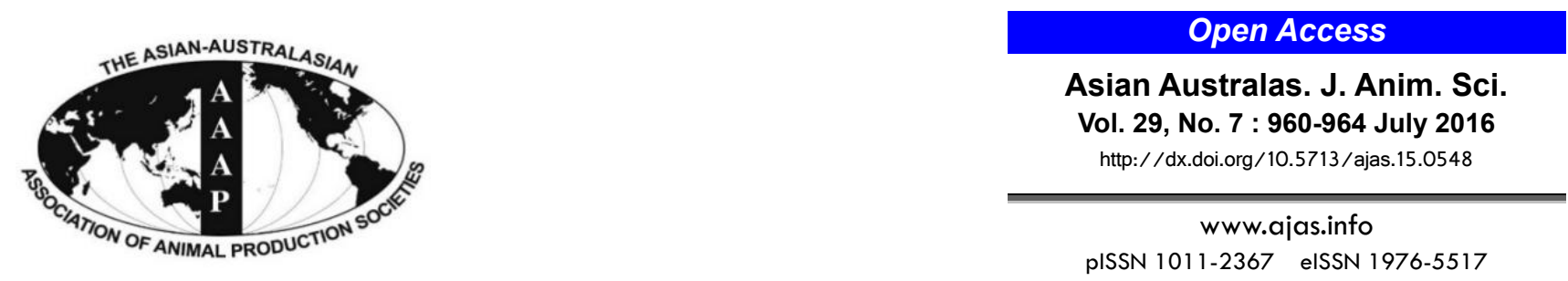

\title{
The Effects of Dietary Phosphorus on the Growth Performance and Phosphorus Excretion of Dairy Heifers
}

\author{
B. Zhang, C. Wang' ${ }^{1}$ Z. H. Wei, H. Z. Sun, G. Z. Xu², J. X. Liu, and H. Y. Liu* \\ Institute of Dairy Science, College of Animal Science, Zhejiang University, Hangzhou 310058, China
}

\begin{abstract}
The objective of this study was to investigate the effects of reducing dietary phosphorus (P) on the frame size, udder traits, blood parameters and nutrient digestibility coefficient in 8- to 10-month-old Holstein heifers. Forty-five heifers were divided into 15 blocks according to the mo of age and were randomly assigned one of three dietary treatments: $0.26 \%$ (low P [LP]), $0.36 \%$ (medium $\mathrm{P}[\mathrm{MP}]$ ), or $0.42 \%$ (high P [HP]) (dry matter basis). Samples were collected at the wk $1,4,8$. The results show that low dietary P had no effect on body measurement. The blood $\mathrm{P}$ concentration decreased with decreasing dietary $\mathrm{P}(\mathrm{p}<0.05)$, while the blood calcium content of LP was higher than that of the MP and HP groups $(\mathrm{p}<0.05)$, though still in the normal range. The serum contents of alkalinephosphatase, potassium, and magnesium were similar among the treatments. No differences were found in all nutrients' apparent digestibility coefficients with varied dietary P. However, with P diet decreased from HP to LP, the total fecal P and urine P concentration declined significantly, as did fecal water soluble $\mathrm{P}(\mathrm{p}<0.05)$. In conclusion, reducing the dietary $\mathrm{P}$ from $0.42 \%$ to $0.26 \%$ did not negatively affect the heifers' growth performance but did significantly lessen manure P excretion into the environment. (Key Words: Heifers, Growth Performance, Phosphorus, Phosphorus Excretion)
\end{abstract}

\section{INTRODUCTION}

Phosphorus (P) is known to play an important role in various events of animal production and reproduction, including adenosine triphosphate (ATP), buffering systems, cell signaling, structure and strength of bones, and synthesis of cell walls, RNA and DNA (Hill et al., 2008; Geisert et al., 2010). Currently, the most critical environment problem in China is water pollution, and the excessive concentration of $\mathrm{P}$ has been recognized as a major cause of eutrophication in surface water (Correll, 1998; Imura, 2013). Previous studies demonstrated that the average amount of total $\mathrm{P}$ was 0.077 $\mathrm{mg} / \mathrm{L}$ in Taihu Lake, of which animal and poultry manure $\mathrm{P}$ account for 46\% (Li et al., 2000; Imura, 2013). Therefore, improving the efficiency of $\mathrm{P}$ utilization and lessening manure $\mathrm{P}$ excretion are the important ways to reduce the

\footnotetext{
* Corresponding Author: H. Y. Liu. Tel: +86-571-88982965, Fax: +86-571-88982930, E-mail: hyliu@zju.edu.cn

${ }^{1}$ College of Animal Science and Technology, Zhejiang A \& F University, Hangzhou, 311300, China.

${ }^{2}$ Institute of Shanghai Dairy Science, Shanghai 200032, China.

Submitted Jul. 1, 2015; Revised Sept. 4, 2015; Accepted Oct. 5, 2015
}

potential P pollution of freshwater.

A recent survey demonstrated that livestock producers in eastern China fed heifers $0.46 \%$ to $0.72 \%$ dietary $\mathrm{P}$ on a dry matter (DM) basis (Guo, 2013), which was higher than the amount recommended by the NRC (2001) $(0.25 \%$ to $0.29 \%$ diet $\mathrm{P}$ [DM basis], body weight [BW] from 250 to $350 \mathrm{~kg}$, average daily gain $[\mathrm{ADG}]=1,000 \mathrm{~g}$ ). The high content of dietary $\mathrm{P}$ was enabling heifers to reach puberty and pregnancy faster (Hill et al., 2007). However, many studies indicated that overfeeding $\mathrm{P}$ is not necessary, because increase $\mathrm{P}$ in manure and augments the expense of the producer (Wu et al., 2000; Valk et al., 2002; Bjelland et al., 2011). Tallam et al. (2005) reported no effect on ovarian activity, reproduction, or lactation benefit when feeding multiparous Holstein cows $0.35 \%$ to $0.47 \%$ of dietary P. In addition, excess dietary $\mathrm{P}$ was simply excreted, suggesting that the supplied additional mineral $\mathrm{P}$ in grain-based diets is not necessary. There was a significant amount of information on $\mathrm{P}$ excretion reduction from lactating cows, but few data on heifers are available. Therefore, the objective of this study was to assess whether lessening dietary P affects the growth performance of dairy heifers in 
China.

\section{MATERIAL AND METHODS}

\section{Animals and experimental diets}

The use of heifers was approved by the Animal Care Committee of Zhejiang University, Hangzhou, China. Forty-five Holstein heifers were divided into 15 blocks according to the mo of age $(9.3 \pm 0.8)$ and were randomly assigned one of the following treatments: $0.26 \%$ (low $\mathrm{P}$ [LP]), $0.36 \%$ (medium P [MP]), and $0.42 \%$ (high P [HP]) (Table 1). The LP diet contained no supplemental P, whereas the other 2 diets were obtained by adding different amounts of dicalcium phosphate. The amount of $\mathrm{P}$ in the LP diet was near the level recommended by the NRC (BW from 250 to $350 \mathrm{~kg}, \mathrm{ADG}=1,000 \mathrm{~g}$ ), the MP dietary P level was close to the Chinese dairy cow feeding standard recommendations (NY/T 34-2004, BW from 250 to $350 \mathrm{~kg}$,

Table 1. Ingredients and nutrient composition of the diet

\begin{tabular}{|c|c|c|c|}
\hline \multirow{2}{*}{ Items } & \multicolumn{3}{|c|}{ Dietary treatment } \\
\hline & HP & MP & LP \\
\hline \multicolumn{4}{|l|}{ Ingredient, \% DM basis } \\
\hline Chinese wild rye & 39.8 & 40.0 & 39.9 \\
\hline Corn silage & 25.1 & 25.1 & 25.2 \\
\hline Corn & 13.9 & 14.0 & 14.0 \\
\hline Barley & 6.1 & 6.3 & 6.3 \\
\hline Rapeseed meal & 4.6 & 4.7 & 4.7 \\
\hline Soybean meal & 1.7 & 1.7 & 1.7 \\
\hline DDGS(corn) & 4.8 & 4.9 & 4.9 \\
\hline Peptide protein & 0.9 & 0.9 & 0.9 \\
\hline Mineral-Vitamin premix ${ }^{1}$ & - & - & 2.4 \\
\hline P mineral-Vitamin premix ${ }^{2}$ & 2.2 & 2.4 & - \\
\hline Di-calcium phosphate & 0.99 & - & - \\
\hline \multicolumn{4}{|l|}{ Analyzed chemical composition } \\
\hline $\mathrm{CP}$ & 11.2 & 11.2 & 11.1 \\
\hline NDF & 55.3 & 54.2 & 56.0 \\
\hline $\mathrm{ADF}$ & 29.0 & 28.4 & 28.7 \\
\hline $\mathrm{P}$ & 0.42 & 0.36 & 0.26 \\
\hline $\mathrm{Ca}$ & 1.0 & 0.9 & 0.9 \\
\hline $\mathrm{EE}$ & 2.5 & 2.3 & 2.4 \\
\hline Ash & 6.9 & 6.9 & 6.8 \\
\hline $\mathrm{NE}_{\mathrm{G}}(\mathrm{Mcal} / \mathrm{kg})^{3}$ & 0.95 & 0.96 & 0.96 \\
\hline
\end{tabular}

LP, low phosphorus (P); MP, medium P; HP, high P; DM, dry matter DDGS, distillers dried grains with solubles; CP, crude protein; NDF, neutral detergent fiber; $\mathrm{ADF}$, acid detergent fiber; $\mathrm{EE}$, ether extract; $\mathrm{NE}_{\mathrm{G}}$, net energy for gain.

${ }^{1}$ Mineral-vitamin premix per kg containing: Ca (g) 166; P (g) 0; Fe (mg) 1,800; Cu (mg) 630; Mn (mg) 630; Zn (mg) 2,940; Se (mg) 21; I (mg) 38; Co (mg) 8; Vitamin A (IU) 240,000; Vitamin D (IU) 60,000; Vitamin E (IU) 1,200

${ }^{2}$ P Mineral-vitamin premix per kg containing: Ca (g) 166; P (g) 70; Fe (mg) 1,800; Cu (mg) 630; Mn (mg) 630; Zn (mg) 2,940; Se (mg) 21; I (mg) 38; Co (mg) 8; Vitamin A (IU) 240,000; Vitamin D (IU) 60,000; Vitamin E (IU) 1,200.

${ }^{3}$ As calculated by NRC (2001).
$\mathrm{ADG}=1,000 \mathrm{~g}$ ), and the HP diet contained P commonly fed by livestock producers in the east region of China (Guo, 2013). In order to avoid excessive fattening, all heifers were limited feeding, $2.1 \%$ of BW, and average dry matter intake (DMI) of each group was measured weekly. Heifers were housed in a tie-stall barn with free access to water and fed 3 times daily at 06:30, 14:00, and 20:30 h. At each feeding time, mixed concentrates were offered first, and then corn silage and grass hay were provided. The experiment was conducted from October until December 2013.

\section{Measurements and analytical methods}

A proportional amount of feed offered was collected weekly. Samples were dried in a forced oven at $55^{\circ} \mathrm{C}$ for 48 $\mathrm{h}$ and then milled through a Wiley mill with1-mm screen, and analyzed for crude protein (CP), Ca, P, ash, ether extract (AOAC, 1990), fecal water soluble P (Dou et al., 2002), neutral detergent fiber (NDF; Van Soest et al., 1991), acid detergent fiber (ADF; Van Soest et al., 1991). Spot fecal and urinary samples collected at 07:00, 14:30, and 20:30 h on the $\mathrm{d} \mathrm{3,27}$, and 53 were mixed across hours with a day as described by Wang et al. (2014), and sampled for later analysis. The record of hip height, body high, body length, heart girth, and teat length were taken at the $\mathrm{d} 2,26$, and 52. Blood samples $(5 \mathrm{~mL})$ were collected from the coccygeal vein on the $\mathrm{d} 1,25$, and 51 , and centrifuged at $3,000 \times \mathrm{g}$ for $10 \mathrm{~min}$ to collect serum, which were frozen at $-20^{\circ} \mathrm{C}$. Alkalinephosphatase (ALP), Ca, P, magnesium (Mg) and potassium $(\mathrm{K})$ serum concentrations were analyzed using a HITACHI (7020) Automatic Analyzer, and kits were provided by NINGBO MEDICALSYSTEM BIOTECHNOLOGY CO., LTD (Zhejiang, China).

\section{Calculations and statistical analysis}

The BW of each cow was calculated based on the measurement of heart girth and body length using the following equation: $\mathrm{BW}(\mathrm{kg})=$ heart girth ${ }^{2}(\mathrm{~m}) \times$ body length (m) $\times 96.475$ (Heinrichs et al., 1992; Shen et al., 2010; Yu et al., 2014). Apparent nutrient digestibility was calculated by using the following equation: Apparent digestibility $=100$ $\left[\left(\mathrm{N}_{\mathrm{f}} / \mathrm{N}_{\mathrm{d}}\right) \times\left(\mathrm{M}_{\mathrm{d}} / \mathrm{M}_{\mathrm{f}}\right)\right] \times 100$, where $\mathrm{N}_{\mathrm{f}}=$ concentration of the nutrient in the fecal, $\mathrm{N}_{\mathrm{d}}=$ concentration of the nutrient in the consumed diet, $\mathrm{M}_{\mathrm{d}}=$ concentration of the acid insoluble ash (AIA) in the consumed diet and $\mathrm{M}_{\mathrm{f}}=$ concentration of the AIA in the fecal (Stojanovic et al., 2014).

Data on DMI, P intake, body measurements, nutrient apparent digestibility coefficient, and fecal and urine $\mathrm{P}$ were analyzed using GLM of SAS (SAS Institute, 2000). Blood biochemical parameters were analyzed using PROC MIXED of SAS (SAS Institute, 2000); treatment, time, treatment $\times$ time, and block were included as fixed effects in the model; Heifers were the random effect. Probability values of $p<0.05$ were used to define statistical significance 
and values of $\mathrm{p}<0.10$ and $\mathrm{p} \geq 0.05$ were accepted as statistical trends.

\section{RESULTS AND DISCUSSION}

\section{Feed ingredients, experimental diets, dry matter intake and $P$ intake}

The experimental diets had a similar composition of ingredients but with different $\mathrm{P}$ concentrations of $0.26 \%$, $0.36 \%$, and $0.42 \%$ (DM basis, Table 1). The $\mathrm{Ca}: \mathrm{P}$ is different, but it is still within the normal range. NRC (2001) recommended that $\mathrm{Ca}: \mathrm{P}$ is not critical on absorption of $\mathrm{P}$ and $\mathrm{Ca}$ in ruminants, unless the ratio is $>7: 1$ or $<1: 1$. DMI were similar among the treatments, average $2.1 \%$ of $\mathrm{BW}$, which result from restricted feeding. Kertz (1987) believed that Holstein heifers must gain greater than $800 \mathrm{~g} / \mathrm{d}$ and less than $1,000 \mathrm{~g} / \mathrm{d}$ that not only could make heifers reach a BW of $570 \mathrm{~kg}$ at $24 \mathrm{mo}$ of age, but also could avoid heifers' excessive fattening. The amount of $\mathrm{P}$ intake was increased with the increase of dietary $\mathrm{P}$ concentration (Table 2).

\section{Body measurements and serum parameters}

The skeletal measurements and calculated BW of Holstein heifers fed diets containing $0.26 \%, 0.36 \%$, and $0.42 \% \mathrm{P}$ were presented in Table 3 . Heifers fed $0.26 \% \mathrm{P}$ were similar in every measure of frame growth compared to the other two groups, suggesting that low-P ration had no effect on skeletal development. These observations are supported by Bjelland et al. (2011) and Esser et al. (2009), who reported no differences in skeletal growth of heifers due to the dietary addition of supplemental P. Similar results were also obtained from Hill et al. (2007). Mammary development is one of the most important criteria used to estimate lactation performance, and high-producing heifers tended to have lengthier teats and larger distances between teats compared with poor-producing heifers (Lin et al., 1987). This study determined that front teat length, rear teat length and teat distance were not differ among the 3 treatments (Figure 1), which indicated that the mammary development of the heifer was not affected by LP. The serum ALP, $\mathrm{K}, \mathrm{Mg}$ concentrations were similar among treatments (Table 4), although a numerical decrease in ALP was observed with increased dietary $P(p=0.09)$. The serum $P$ decreased with decreasing dietary $P(p<0.05)$ and the serum $\mathrm{P}$ concentration of LP was consistent with results

Table 2. DMI and P intake of 8- to10-month-old Holstein heifers

\begin{tabular}{lccccc}
\hline \multirow{2}{*}{ Item } & \multicolumn{3}{c}{ Dietary treatment } & \multirow{2}{*}{ SEM } & \multirow{2}{*}{ p-value } \\
\cline { 2 - 4 } & HP & MP & LP & & \\
\hline DMI $(\mathrm{kg})$ & 5.98 & 6.00 & 5.98 & 0.31 & 0.99 \\
P intake $(\mathrm{g} / \mathrm{d})$ & 25.13 & 21.60 & 15.57 & 1.12 & $<0.01$ \\
\hline
\end{tabular}

DMI, dry matter intake; HP, high phosphorus (P); MP, medium P; LP, low $\mathrm{P}$; SEM, standard error of the mean.
Table 3. Calculated BW, and body measurements of 8- to10month-old Holstein heifers

\begin{tabular}{lccccc}
\hline \multirow{2}{*}{ Item } & \multicolumn{3}{c}{ Dietary treatment } & \multirow{2}{*}{ SEM } & \multirow{2}{*}{ p-value } \\
\cline { 2 - 4 } & HP & MP & LP & & \\
\hline Calculated BW (kg) & 289 & 291 & 297 & 4.86 & 0.52 \\
Heart girth & & & & & \\
$\quad$ Initial $(\mathrm{cm})$ & 145.07 & 145.73 & 146.53 & 2.84 & 0.88 \\
$\quad$ Final $(\mathrm{cm})$ & 153.00 & 152.80 & 152.33 & 2.70 & 0.97 \\
$\quad$ Change $(\mathrm{cm} / \mathrm{d})$ & 0.14 & 0.13 & 0.10 & 0.02 & 0.20 \\
Body length & & & & & \\
$\quad$ Initial $(\mathrm{cm})$ & 128.93 & 128.83 & 132.33 & 2.51 & 0.30 \\
$\quad$ Final $(\mathrm{cm})$ & 134.87 & 135.13 & 136.60 & 2.67 & 0.78 \\
$\quad$ Change $(\mathrm{cm} / \mathrm{d})$ & 0.11 & 0.11 & 0.08 & 0.03 & 0.51 \\
Body height & & & & & \\
$\quad$ Initial $(\mathrm{cm})$ & 107.80 & 108.60 & 110.80 & 2.37 & 0.43 \\
$\quad$ Final $(\mathrm{cm})$ & 115.40 & 115.20 & 116.40 & 1.81 & 0.78 \\
Change $(\mathrm{cm} / \mathrm{d})$ & 0.13 & 0.12 & 0.10 & 0.02 & 0.14 \\
Cannon bone & & & & & \\
$\quad$ Initial $(\mathrm{cm})$ & 16.31 & 15.93 & 15.98 & 0.31 & 0.42 \\
$\quad$ Final $(\mathrm{cm})$ & 16.48 & 16.12 & 16.11 & 0.35 & 0.49 \\
Change $(\mathrm{cm})$ & 0.17 & 0.18 & 0.13 & 0.24 & 0.97 \\
\hline
\end{tabular}

BW, body weight; LP, low phosphorus (P); MP, medium P; HP, high P; SEM, standard error of the mean.

${ }^{1}$ Change in body measurements from the beginning until the end of the trial.

${ }^{2}$ Value indicate cannon bone circumference.

reported by Bjelland (2011), who noting that blood P was $2.65 \mathrm{mmol} / \mathrm{L}$ with $0.30 \%$ dietary $\mathrm{P}$ in 8 -month-old heifers. Wu et al. (2000) observed that serum $P$ appeared higher for cows fed a high $\mathrm{P}$ diet compared with those receiving a low $\mathrm{P}$ diet; redundant dietary $\mathrm{P}$ was not utilized and was simply excreted in manure. The serum Ca content of heifers in LP was higher than that in MP and HP groups $(p<0.05)$. Breves et al. (1985) reported that serum $\mathrm{Ca}$ increased when the amount of dietary $\mathrm{P}$ fed to sheep was decreased. Moreover, Kichura et al. (1982) believed that when dietary calcium is high, low dietary phosphorus seems helpful to enhance the activation of intestinal calcium absorption. No significant

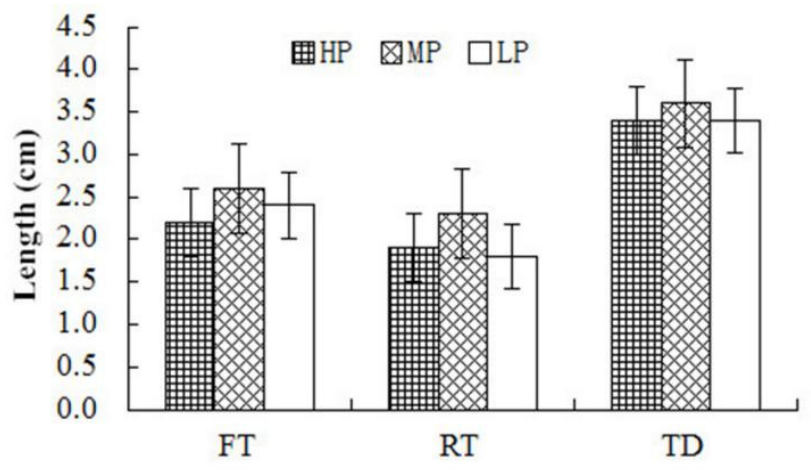

Figure 1. Udder measures of 8- to 10-month-old Holstein heifers fed varied dietary phosphorus (P). LP, low P; MP, medium P; HP, high P; FT, front teat length; RT, rear teat length; TD, teat distance, distance around gland front to rear. 
Table 4. Effect of different dietary phosphorus (P) on serum biochemical parameters of 8- to 10-month-old Holstein heifers

\begin{tabular}{|c|c|c|c|c|c|c|c|}
\hline \multirow{2}{*}{ Item } & \multicolumn{3}{|c|}{ Dietary treatment } & \multirow{2}{*}{ SEM } & \multicolumn{3}{|c|}{ p-value } \\
\hline & HP & MP & LP & & Diet & Time & Diet $\times$ time \\
\hline $\begin{array}{l}\text { ALP } \\
(\mathrm{U} / \mathrm{L})\end{array}$ & 120.7 & 125.3 & 135.9 & 4.85 & 0.09 & $<0.01$ & 0.95 \\
\hline $\begin{array}{l}\mathrm{Ca} \\
(\mathrm{mmol} / \mathrm{L})\end{array}$ & $2.46^{\mathrm{a}}$ & $2.46^{\mathrm{a}}$ & $2.54^{b}$ & 0.02 & 0.03 & $<0.01$ & 0.49 \\
\hline $\begin{array}{l}\mathrm{P} \\
(\mathrm{mmol} / \mathrm{L})\end{array}$ & $2.84^{\mathrm{a}}$ & $2.71^{\mathrm{ab}}$ & $2.64^{b}$ & 0.05 & 0.02 & 0.03 & 0.50 \\
\hline $\begin{array}{l}\mathrm{K}_{(\mathrm{mmol} / \mathrm{L})}\end{array}$ & 5.14 & 5.19 & 5.06 & 0.07 & 0.45 & $<0.01$ & 0.36 \\
\hline $\begin{array}{l}\mathrm{Mg} \\
(\mathrm{mmol} / \mathrm{L})\end{array}$ & 0.80 & 0.84 & 0.80 & 0.02 & 0.31 & $<0.01$ & 0.06 \\
\hline
\end{tabular}

LP, low phosphorus (P); MP, medium P; HP, high P; SEM, standard error of the mean; ALP, alkalinephosphatase.

Values with different superscripts $(\mathrm{a}, \mathrm{b})$ are significantly different $(\mathrm{p}<0.05)$.

diet $\times$ time interaction was observed for serum $\mathrm{P}, \mathrm{Ca}, \mathrm{K}, \mathrm{Mg}$, and ALP.

\section{Apparent digestibility of nutrients and manure $P$ excretion}

Even though the heifers in HP treatment consumed more $\mathrm{P}$, the apparent $\mathrm{P}$ digestibility coefficients did not differ among the treatments (Table 5). Other research noted that the apparent digestibility of $\mathrm{P}$ in lactating cows less than $40 \%$ equates to an excessive of $\mathrm{P}$ intake ( $\mathrm{Wu}$ et al., 2000), but it is still unknown for growing heifers. In regard to other nutrients, low dietary $\mathrm{P}$ had no effect on NDF, ADF, and the $\mathrm{CP}$ apparent digestibility coefficients, which is in agreement with previous results (Odongo et al., 2007; Xu et al., 2011). The excretion of $P$ in manure was presented in Table 5. The total fecal P concentration decreased 35.62\%, and the urine $\mathrm{P}$ concentration was reduced by $69.35 \%$ as dietary $\mathrm{P}$ decreased from $0.42 \%$ to $0.26 \% \quad(\mathrm{p}<0.05)$.

Table 5. Fecal phosphorus $(\mathrm{P})$ and urine $\mathrm{P}$ and apparent digestibility coefficients for $\mathrm{CP}, \mathrm{P}, \mathrm{NDF}$, and ADF of heifers fed different dietary $\mathrm{P}$ concentrations

\begin{tabular}{lccccc}
\hline \multirow{2}{*}{ Item } & \multicolumn{3}{c}{ Dietary treatment } & \multirow{2}{*}{ SEM } & \multirow{2}{*}{ p-value } \\
\cline { 2 - 5 } & HP & MP & LP & & \\
\hline CP (\%) & 54.3 & 58.5 & 58.3 & 0.51 & 0.13 \\
P (\%) & 32.7 & 32.2 & 33.1 & 0.98 & 0.98 \\
NDF (\%) & 54.7 & 56.6 & 55.4 & 0.58 & 0.76 \\
ADF (\%) & 52.1 & 52.7 & 50.3 & 0.62 & 0.79 \\
Fecal total P (\% of DM) & $0.73^{\mathrm{a}}$ & $0.66^{\mathrm{b}}$ & $0.47^{\mathrm{c}}$ & 0.006 & $<0.01$ \\
Fecal water soluble P & $0.38^{\mathrm{a}}$ & $0.41^{\mathrm{a}}$ & $0.26^{\mathrm{b}}$ & 0.005 & $<0.01$ \\
$\quad(\%$ of DM) & & & & & \\
Urine P (g/kg) & $0.62^{\mathrm{a}}$ & $0.22^{\mathrm{b}}$ & $0.19^{\mathrm{b}}$ & 0.025 & $<0.01$ \\
\hline
\end{tabular}

LP, low phosphorus (P); MP, medium P; HP, high P; SEM, standard error of the mean; $\mathrm{CP}$, crude protein; NDF, neutral detergent fiber; $\mathrm{ADF}$, acid detergent fiber; DM, dry matter.

Values with different superscripts ( $a, b$, and $c)$ are significantly different $(\mathrm{p}<0.05)$
Nowadays, water soluble $\mathrm{P}$ has been seen as a viable index in environmental protection (Dou et al., 2002). This study determined that water soluble $\mathrm{P}$ account for more than $50 \%$ of total fecal $\mathrm{P}$ and similar with the results reported by Dou (2002) and Bernier (2014); and high dietary P not only led to higher total fecal $\mathrm{P}$ content, but it also increased the proportion of water soluble $\mathrm{P}(\mathrm{p}<0.05)$. Previous studies demonstrated that fecal $\mathrm{P}$ excretion decreased by $23 \%$ as dietary $\mathrm{P}$ lessened by 0.1 percentage points ( $\mathrm{Wu}$ et al., 2000); similar reductions in fecal $\mathrm{P}$ were also reported by Tallam (2005), and our results are also consistent with their findings.

\section{CONCLUSIONS}

In conclusion, this study revealed that reducing dietary P from $0.42 \%$ to $0.26 \%$ did not negatively affect heifers' growth performance, though it did significantly reduce manure $\mathrm{P}$ excretion into the environment. The dietary $\mathrm{P}$ content of $0.26 \%$ was sufficient for 8- to10-month-old Holstein heifers in China. Depending on the feed ingredients used, this concentration of $\mathrm{P}$ can be obtained without the addition of inorganic $\mathrm{P}$ supplement to the feed. However, further studies are required to identify the longterm effects of low dietary $\mathrm{P}$ on heifers.

\section{CONFLICT OF INTEREST}

We certify that there is no conflict of interest with any financial organization regarding the material discussed in the manuscript.

\section{ACKNOWLEDGMENTS}

This work was supported by the National Key Technology R \&D of China (no. 2012BAD12B02). The authors gratefully thank all staff at the Shanghai Lianjiang (Anhui) dairy farm for their inputs to this study.

\section{REFERENCES}

AOAC. 1990. Official Methods of Analysis. 15th edn. Association of Official Analytical Chemists, Arlington, VA, USA.

Bernier, J. N., M. Undi, K. H. Ominski, G. Donohoe, M. Tenuta, D. Flaten, J. C. Plaizier, and K. M. Wittenberg. 2014. Nitrogen and phosphorus utilization and excretion by beef cows fed a low quality forage diet supplemented with dried distillers grains with solubles under thermal neutral and prolonged cold conditions. Anim. Feed Sci. Technol. 193:9-20.

Bjelland, D. W., K. A. Weigel, P. C. Hoffman, N. M. Esser, and W. K. Coblentz. 2011. The effect of feeding dairy heifers diets with and without supplemental phosphorus on growth, reproductive efficiency, heath, and lactation performance. J. Dairy Sci. 94:6233-6242.

China Standard NY/T-34. 2004. Feeding Standard of Dairy Cattle. 
China Agric. Press, Beijing, China.

Correll, D. L. 1998. The role of phosphorus in the eutrophication of receiving waters: A review. J. Environ. Qual. 27:261-266.

Dou, Z., K. F. Konwlton, R. A. Kohn, Z. Wu, L. D. Satter, G. Jhang, J. D. Toth, and J, D. Ferguson. 2002. Phosphorus characteristics of dairy feces affected by diets. J. Environ. Qual. 31:2058-2065.

Esser, N. M., P. C. Hoffman, W. K. Coblentz, M. W. Orth, and K. A. Weigel. 2009. The effect of dietary phosphorus on bone development in dairy heifers. J. Dairy Sci. 92:1741-1749.

Geisert, B. G., G. E. Erickson, T. J. Klopfenstein, C. N. Macken, M. K. Luebbe, and J. C. MacDonald. 2008. Phosphorus requirement and excretion of finishing beef cattle fed different concentrations of phosphorus. J. Anim. Sci. 88:2393-2402.

Guo, C. 2013. The Analysis of Diets Feed Nutrients and The Status of Nitrogen and Phosphorus Use in Scale Dairy Farms Which Are in The Eastern Region. BA Thesis. Zhejiang University, Hangzhou, China.

Heinrichs, A. J., G. W. Rogers, and J. B. Cooper. 1992. Predicting body weight and wither height in Holstein heifers using body measurements. J. Dairy Sci. 75:3576-3581

Hill, S. R., K. F. Knowlton, E. Kebreab, J. France, and M. D. Hanigan. 2008. A model of phosphorus digestion and metabolism in the lactating dairy cow. J. Dairy Sci. 91:20212032.

Hill, S. R., K. F. Knowlton, R. E. James, R. E. Pearson, G. L. Bethard, and K. J. Pence. 2007. Nitrogen and phosphorus retention and excretion in late-gestation dairy heifers. J. Dairy Sci. 90:5634-5642.

Imura, H. 2013. Environmental issues in China today: A view from Japan. In: Advances in Asian Human-Environmental Research. (Eds. M. Nüsser) Springer, Verlag, Japan. pp. 72-73.

Kertz, A. F., L. R. Prewitt, and J. M. Ballam. 1987. Increased weight gain and effects on growth parameters of Holstein heifer calves from 3 to 12 months of age. J. Dairy Sci. 70:1612-1622.

Kichura, T. S., R. L. Horst, D. C. Beitz, and E. T. Littledike. 1982. Relationships between prepartal dietary calcium and phosphorus, vitamin D metabolism, and parturient paresis in dairy cows. J. Nutr.112:480-487.

Li, R. G., Y. L. Xia, A. Z. Wu, and Y. Qian. 2000. Pollutants sources and their discharging amount in Taihu Lake Area of Jiangsu Province. J. Lake Sci. 8:147-153.

Lin, C. Y., A. J. Lee, A. J. McAllister, T. R. Batra, G. L. Roy, J. A. Vesely, J. M. Wauthy, and K. A. Winter. 1987. Intercorrelations among milk traits and body and udder measurements in Holstein heifers. J. Dairy Sci. 70:2385-2393.
NRC, 2001. Nutrient Requirements of Dairy Cattle. 7th edn. National Academy Press, Washington, DC. USA.

Odongo, N. E., D. McKnight, A. Koekkoek, J. W. fisher, P. Sharpe, E. Kebreab, J. France, and B. W. McBride 2007. Long-term effects of feeding diets without mineral phosphorus supplementation on the performance and phosphorus excretion high-yielding dairy cows. J. Anim. Sci. 87:639-646.

SAS Institute. 2000. SAS User's Guide: Statistics. Version 8.01. SAS Inst. Inc., Cary, NC, USA.

Shen, J. S., J. Q. Wang, H. Y. Wei, D. P. Bu, P. Sun, and L. Y. Zhou. 2010. Transfer efficiency of melamine from feed to milk in lactating dairy cows fed with different doses of melamine. J. Dairy Sci. 93:2060-2066.

Stojanovic, B., G. Grubic, N. Djordjevic, A. Bozickovic, A. Ivetic, and V. Davidovic. 2014. Effect of physical effectiveness on digestibility of ration for cows in early lactation. J. Anim. Physiol. Anim. Nutr. 98:714-721.

Tallam, S. K., A. D. Ealy, K. A. Bryan, and Z. Wu. 2005. Ovarian activity and reproductive performance of dairy cows fed different amount of phosphorus. J. Dairy Sci. 88:3609-3618.

Valk, H., L. B. J. Sebek, and A. C. Beynen. 2002. Influence of phosphorus intake on excretion and blood plasma and saliva concentrations phosphorus in dairy cows. J. Dairy Sci. 85:2642-2649.

Van-Soest, P. J., H. B. Robertson, and B. A. Lewis. 1991. Methods of dietary fiber, NDF and non-starch polysaccharides in relation to animal nutrition. J. Dairy Sci. 74:3583-3597.

Wu, Z. and L. D. Satter. 2000. Milk production and reproductive performance of dairy cows fed two concentrations of phosphorus for two years. J. Dairy Sci. 83:1052-1063.

Wu, Z., L. D. Satter, and R. Sojo. 2000. Milk production, reproductive performance, and fecal excretion of phosphorus by dairy cows fed three amount of phosphorus. J. Dairy Sci. 83:1028-1041.

Wang, C., Z. Liu, D. M. Wang, J. X. Liu, H. Y. Liu, and Z. G. Wu. 2014. Effect of dietary phosphorus content on milk production and phosphorus excretion in dairy cows. J. Anim. Sci. Biotechnol. 5:23.

Xu, J. H., W. Zhang, J. Huang, J. Jiang, C. M. Sun, and F. Mo. 2011. Effects of dietary phosphorus levels on apparent digestibility of nutrients in Simmental crossbreed replacement heifers. Chinese J. Anim. Nutr. 23:589-596.

Yu, Z., Y. X. Gao, Y. F. Cao, Q. F. Li, and J. G. Li. 2014. Study on growth and development pattern of Chinese Holstein calf and heifer. China Anim. Husb. Vet. Med. 41:121-125. 